\title{
XXVII. The rise of $\gamma$-ray activity of radium emanation
}

\section{F.P. Slater M.Sc. B.A.}

To cite this article: F.P. Slater M.Sc. B.A. (1922) XXVII. The rise of $\gamma$-ray activity of radium emanation, Philosophical Magazine Series 6, 44:260, 300-304, DOI: 10.1080/14786440808634001

To link to this article: http://dx.doi.org/10.1080/14786440808634001

$$
\text { 曲 Published online: } 08 \text { Apr } 2009 .
$$

\section{Submit your article to this journal $₫$}

$$
\text { Џlll Article views: } 4
$$

Q View related articles $\sqsubset$

4 Citing articles: 1 View citing articles 준 
apart of their centres have already been stated; and both modified models have mean areas of projection which are very easily calculated. The upper limit thus determined proves to be $2 \cdot 12$ times the collision area of the argon atom ; the lower limit is 1.90 times the same area. Using the known value $0.648 \times 10^{-15} \mathrm{~cm} .^{2}$ for the collision area of the argon atom, we find that the mean area of projection of the model consisting of two argon atoms with an intermediate neon lies between

$$
\text { and } \quad \begin{aligned}
& 1.37 \times 10^{-15} \mathrm{~cm}^{2} \\
& 1.23 \times 10^{-15} \mathrm{~cm} .^{2}
\end{aligned}
$$

We may venture to predict with some confidence that the mean collision area of the $\mathrm{CS}_{2}$ molecule, when determined, will be found to be between the above values. A more exact estimate could of course be made, but the degree of accuracy at present attainable in determining molecular dimensions from viscosity measurements is not sufficient to render the additional calculation worth while.

\section{Summary.}

On the assumption of the validity of the Lewis-Langmuir view of molecular constitution, the probable behaviour during encounters has been examined for the molecules of carbon oxysulphide and carbon bisulphide. In the former case it is shown that the molecular dimensions as derived from the application of the kinetic theory to the viscosity measurements of C. J. Smith, are in striking accordance with the rosults of the above examination. In the latter case comparison is not yet possible, on account of the absence of necessary data.

Imperial College of Science and Technology, May 11th, 1922.

XXVII. The Rise of $\gamma$-Ray Activity of Radium Emanation. By F. P. Slater, M.Sc. (Vict.), B.A. (Cantab.)*.

$\mathrm{N}$ a previous paper $\dagger$ it has been shown how the initial 1 rise of $\gamma$-ray activity, starting from pure radium emanation, depended on the nature of the walls of the tube containing the gas, the reason being that a small but

* Communicated by Prof. Sir E. Rutherford, F.R.S.

† Slater, Phil. Mag. vol. xlii. p. 904 (1921). 
detectable $\gamma$ radiation was excited in the walls by the impact of the $\alpha$ particles emitted by the emanation. The amount of this excited radiation was, however, very small when the walls of the tube were composed of atoms of low atomic weight, and for a lining of pure paper the $\gamma$-ray activity of the emanation and its products was found to rise practically from zero. Under such conditions the $\gamma$ radiations from the tube are due only to the products radium $B$ and radium $\mathrm{C}$.

Taking the number of emanation atoms disintegrating per second at initial time as unity, the number of radium-B atoms disintegrating per second at any subsequent time $t$ is

$$
\lambda_{2} \lambda_{3} \sum_{\lambda=1,2,3} \frac{e^{-\lambda_{1} t}}{\left(\lambda_{2}-\lambda_{1}\right)\left(\lambda_{3}-\lambda_{1}\right)},
$$

where $\lambda_{1}, \lambda_{2}, \lambda_{3}$ are the transformation constants of the emanation and the products $\mathrm{A}, \mathrm{B}$, and $\mathrm{C}$ respectively. This quantity is tabulated for various times up to 220 minutes at the end of this paper (Table II.).

Similarly, the number of radium-C atoms disintegrating per second at time $t$ is

$$
\lambda_{2} \lambda_{3} \lambda_{4} \sum_{\lambda=1,2.3,4} \frac{e^{-\lambda_{2} t}}{\left(\lambda_{2}-\lambda_{1}\right)\left(\lambda_{3}-\lambda_{1}\right)\left(\lambda_{4}-\lambda_{1}\right)} .
$$

Tables for this quantity for various times up to 258 minutes have been given by Moseley and Makower * and by Rutherford $\dagger$.

The rise in $\gamma$-ray activity of a tube filled initially with pure emanation can therefore be represented by

$$
\begin{aligned}
& \mathrm{K} \lambda_{2} \lambda_{3} \sum_{\lambda=1,2,3} \frac{e^{-\lambda_{1} t}}{\left(\lambda_{2}-\lambda_{1}\right)\left(\lambda_{3}-\lambda_{1}\right)} \\
& +(1-\mathrm{K}) \lambda_{2} \lambda_{3} \lambda_{4} \sum_{\substack{1,2,3,4 \\
\left(\lambda_{2}-\lambda_{1}\right)\left(\lambda_{3}-\lambda_{1}\right)\left(\lambda_{4}-\lambda_{1}\right)}}
\end{aligned}
$$

where $\mathrm{K}$ is the fraction of the ionization, measured under given absorption conditions, due to radium $\mathrm{B}$ when in radioactive equilibrium with radium $\mathrm{C}$.

"Thus it is necessary to determine "K." Since the $\gamma$ rays

* Moseley and Makower, Phil. Mag. vol. xxiii. p. 302 (1912).

† Rutherford, 'Radioactive Substances', p. 499. 
from radium $B$ are less penetrating than those from radium $\mathrm{C}$, " K" depends on the thickness of matter through which the radiations pass before entering the ionization chamber. Rise curves have been experimentally determined for different thicknesses of absorption material, both lead and aluminium being used. The values of $\mathrm{K}$ for various thicknesses have been deduced by trial, and are shown in fig. 1.

Fig. 1.

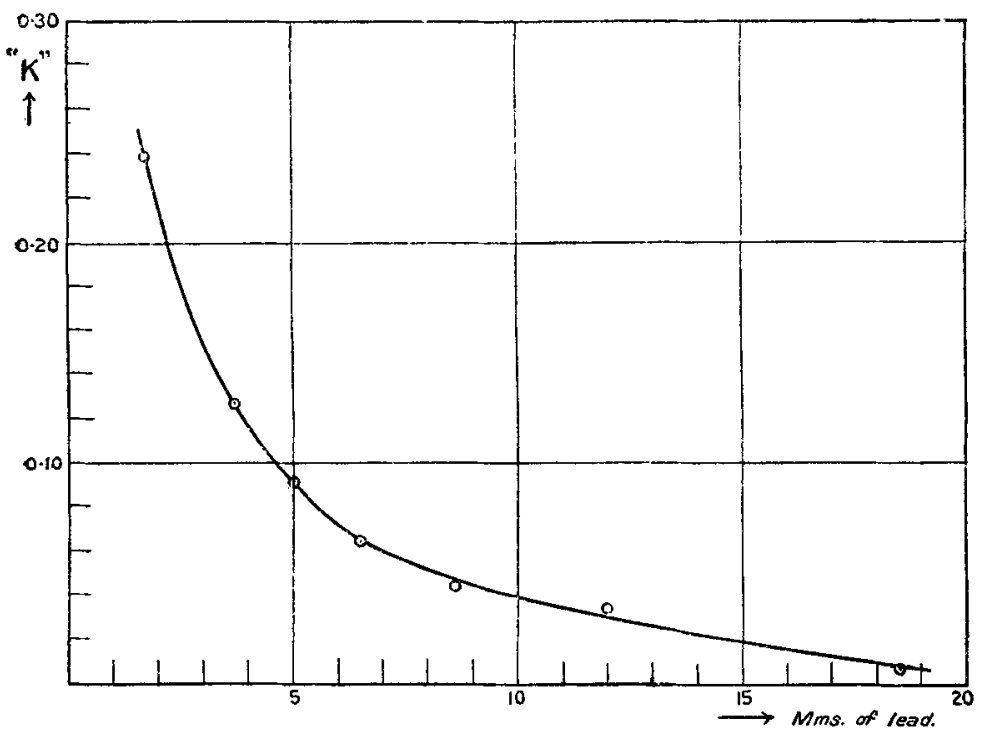

A comparison of the experimental and calculated rise curves of the $\gamma$-ray activity through $12.0 \mathrm{~mm}$. of lead is given in fig. 2. After six minutes from the introduction of pure emanation, the calculated and experimental curves agree very closely.

From these curves the absorption coefficient of the radium B- $\gamma$.rays can be deduced, and the values found are given in Table $\mathrm{I}$. along with comparative determinations by Makower and Moseley (loc. cit.) and Rutherford and Richardson *.

The values of the absorption coefficients for the thicknesses of aluminium are somewhat doubtful, since the supposition of homogeneity of the radium-C $\gamma$ rays is not justifiable through such sinall thicknesses. The increasing

* Rutherford and Richardson, Phil. Mag. rol. xxv. p. 722 (1913). 
value of $\mu\left(\mathrm{cm}^{-1}\right)$ with decreasing thickness of absorption material (see Table I.) is to be expected, since Rutherford and Richardson (loc. cit.) showed that radium $B$ emits certainly two types of radiation having absorption coefficients in aluminium of $0.51 \mathrm{~cm}^{-1}$ and $40.0 \mathrm{~cm} .^{-1}$, and possibly a third type $\left(\mu=230 \cdot 0^{-1}\right.$ in aluminium $)$.

Fig. 2.-Rise of $\gamma$ activity from Radium emanation through 12. $0 \mathrm{~mm}$. of lead.

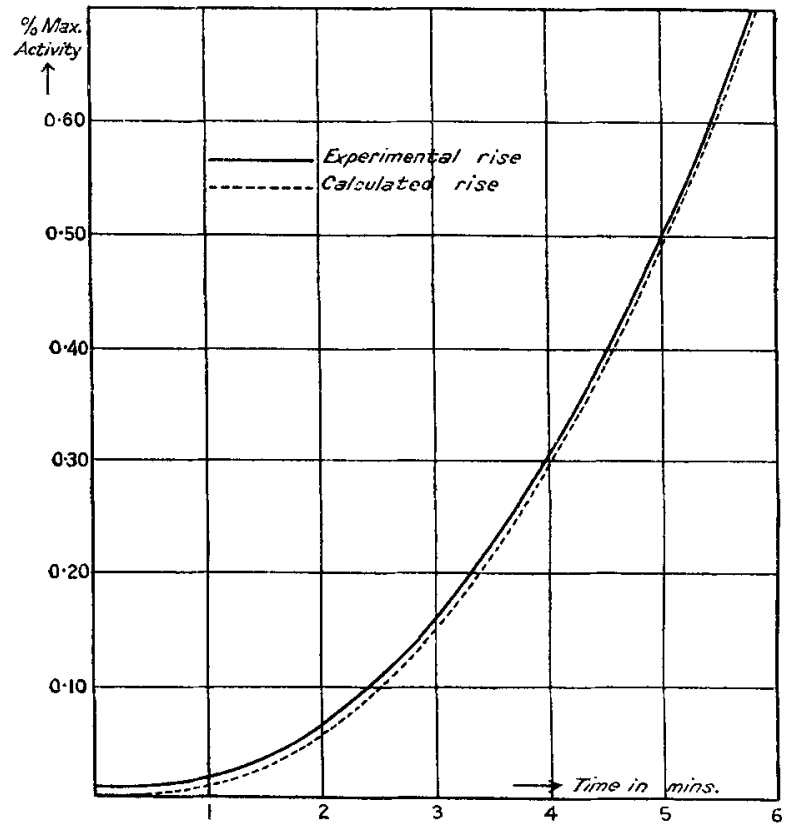

The absorption coefficients in lead only, given in Table I., are corrected for obliquity of the rays entering the electrosoope, and King's correction is used as given in Case II. of his paper *,

$$
\frac{\mathrm{T}_{t}}{\bar{I}_{0}}=\begin{gathered}
f(\mu t)-\cos \theta f[\mu t \sec \theta] \\
1-\cos \theta
\end{gathered}
$$

where $I_{t}$ and $I_{0}$ are the intensities of the radiation emerging through a plate of thickness $t \mathrm{~cm}$. and incident radiation respectively, $\mu$ the absorption coefficient expressed in $\mathrm{cm} .^{-1}$, and $\theta$ the semi-angle of the cone of rays entering the electroscope.

* King, Phil. Mag. vol. xxiii. p. 248 (1912). 
304 Rise of $\gamma$-Ray Activity of Rallium Emanation.

\section{TABLE I.}

Absorbing medium is Lead, except where otherwise shown.

\begin{tabular}{|c|c|c|c|}
\hline $\begin{array}{c}\text { Thiekness of } \\
\text { Absorbing Plate. }\end{array}$ & $\begin{array}{c}\text { Value of } \mu(\mathrm{cm} .-1) \\
\text { for } \\
\text { Radium-B rays. }\end{array}$ & $\begin{array}{l}\text { Moseley } \\
\text { and } \\
\text { Makower. }\end{array}$ & $\begin{array}{l}\text { Rutherford } \\
\quad \text { and } \\
\text { Richardson. }\end{array}$ \\
\hline $160-20 \cdot 0 \mathrm{~mm} \ldots . . \ldots \ldots \ldots \ldots$ & $2 \cdot 7 \mathrm{~cm} .-1$ & - & Varying from \\
\hline $10 \cdot 0-15 \cdot 0, ., \ldots \ldots \ldots \ldots \ldots$ & $2 \cdot 8 \mathrm{~cm} \cdot-1$ & $\cdots$ & $11.0 \mathrm{~cm} .-1$ \\
\hline $4.0-6.0 \quad, \quad \ldots \ldots \ldots \ldots \ldots$ & $4 \cdot 1 \mathrm{~cm} .-1$ & $\begin{array}{l}4 \cdot 0 \mathrm{cw}^{-1} \\
\text { (lead). }\end{array}$ & $\begin{array}{c}\text { to } \\
2.8 \mathrm{~cm} .-1 \text { in }\end{array}$ \\
\hline $1 \cdot 5-2 \cdot 0 \quad, \quad \ldots \ldots \ldots \ldots \ldots \ldots .$. & $6 \cdot 2 \mathrm{~cm} \cdot-1$ & $\begin{array}{l}6.0 \mathrm{~cm}^{-1} \\
\quad(\text { lead) }\end{array}$ & lear. \\
\hline $\begin{array}{l}3 \cdot 0-4 \cdot 0 \text {, (Aluminium) } \\
0.75 \mathrm{~mm} \text {. (Aluminium) } \ldots\end{array}$ & $\begin{array}{r}1.7 \mathrm{~cm} \cdot-1(\mathrm{~A} \\
10.0 \mathrm{~cm} \cdot-1(\mathrm{~A}\end{array}$ & & \\
\hline
\end{tabular}

Table II.

Rise of Radium B from Radium Emanation. Maximum $=0.97480$ is taken as unity.

\begin{tabular}{|c|c|c|c|c|c|}
\hline $\begin{array}{c}\text { Time } \\
\text { in } \\
\text { mins. }\end{array}$ & $\begin{array}{l}\text { Calculated } \\
\text { rise of } \\
\text { Radium B. }\end{array}$ & $\begin{array}{c}\text { Time } \\
\text { iu } \\
\text { mins. }\end{array}$ & $\begin{array}{l}\text { Calculated } \\
\text { rise of } \\
\text { Radium B. }\end{array}$ & $\begin{array}{l}\text { Time } \\
\text { in } \\
\text { mins. }\end{array}$ & $\begin{array}{l}\text { Calculated } \\
\text { rise of } \\
\text { Radium B. }\end{array}$ \\
\hline & 0.00269 & $14 \ldots$ & $0 \cdot 2260$ & $110 \ldots \ldots$ & .0 .9502 \\
\hline & 0.01016 & $16 \ldots \ldots$ & $0 \cdot 2649$ & 120 & 0.9643 \\
\hline 3 & 0.02129 & 18 & $0 \cdot 3023$ & 130 & 0.9750 \\
\hline 4 & 0.03513 & 20 & 03379 & 140 & 0.9835 \\
\hline $5 \ldots$ & 0.05115 & 30 & 0.4942 & 150 & 09886 \\
\hline$\ldots$ & 0.06862 & 40 & 06135 & 160 & 0.9929 \\
\hline $7 \ldots \ldots \ldots$ & 0.08718 & 50 & $0 \cdot 7066$ & 170 & 09956 \\
\hline $8 \ldots \ldots \ldots$ & 010647 & fio $\ldots \ldots \ldots$ & 07780 & 180 & 0.9979 \\
\hline & 0.12622 & $70 \ldots \ldots$ & 08329 & 190 & 0.9992 \\
\hline $10 \ldots \ldots \ldots$ & 0.14624 & 80 & 0.8748 & 200 & 0.9998 \\
\hline ....... & $0 \cdot 16637$ & 90 & 0.9058 & 210 & 0.9999 \\
\hline \multirow[t]{2}{*}{$12 \ldots \ldots \ldots$} & $0 \cdot 186.41$ & 100 & 0.9315 & 214 & $1 \cdot 0000$ \\
\hline & & & & 220 & 0.9999 \\
\hline
\end{tabular}

Summary.

Curves showing the rise of $\gamma$-ray activity from pure radium emanation measured through a wide range of absorption thickness of matter have been determined and utilized in deducing the absorption coefficients of the heterogeneous $\gamma$ radiation from radium B.

My thanks are due to Professor Sir E. Rutherford for his invaluable help in carrying out this research, and to Mr. G. A. R. Crowe for the preparation of the radioactive material. 